\title{
Synthesis and Inhibitory Activity of Schiff base Surfactants Derived from Tannic Acid Against Bacteria and Fungi
}

\author{
N. A. Negm", A. F. El-Farrargy ${ }^{*}$ and I. A. Mohammad \\ Petrochemicals Department, Egyptian Petroleum Research \\ Institute, Cairo, and ${ }^{*}$ Chemistry Department, Faculty of \\ Science, Zagazig University, Zagazig, Egypt.
}

\begin{abstract}
SERIES of tannic acid Schiff base surfactants were synthesized $A$ and their structures were elucidated using microelemental analysis, FTIR and ${ }^{1} \mathrm{H}-\mathrm{NMR}$ data. The molecular weights were determined using viscosity measurements and gel permeation chromatography. The surface activities of the surfactants were determined by surface tension measurements. The antimicrobial activity and minimum inhibitory concentrations were evaluated by disk diffusion assay against gram-positive, gram-negative bacteria and fungi. The antimicrobial data disclosed that the tested compounds demonstrated moderate to excellent microbial inhibitions. Compounds $\mathrm{TGB}_{1}$ showed high potency against the tested strains.
\end{abstract}

Keywords: Surface activity and Biocide.

The development of antimicrobial agents to treat infectious diseases has been one of the most notable achievements of the past century ${ }^{(1)}$. The use of antimicrobial agents resulted in the development of bacterial resistance to the commonly used drugs; as a result a substantial need for design of new classes of antimicrobials is urged. The development of new antimicrobial agents with novel mechanism of action and the optimization of the existing agents by improving both the binding affinity and spectrum of activity while retaining bioavailability and safety profiles have provoked special interest in the medical chemistry. However, the increasing prevalence of one such strategy that has been pursued in the recent years employs a combination of two different active fragments in one molecule ${ }^{(2)}$. Therefore, each drug moiety is designed to bind independently to two different biological targets and synchronously accumulate at both target sites. Such dual-action drugs offer a possibility to overcome the current resistance and reduce the appearance of new resistant strains ${ }^{(3)}$. Schiff bases are efficient antimicrobial agents ${ }^{(4)}$ due to their ability to adsorb onto the cellular membrane. Enhancing the antimicrobial activity of the Schiff bases includes the introduction of some function groups to their chemical structures, e.g., $\mathrm{SH}, \mathrm{NH}, \mathrm{OH}^{(5)}$, heterocyclic or halogens ${ }^{(6-7)}$. Another important feature of

\# Corresponding author: E-mail. nabelnegm@ hotmail.com, Tel. (002-01275704384) 
the antimicrobial agents nowadays, is their ability for biodegradation ${ }^{(8)}$ which makes them environmentally safe. We herein report the design and synthesis of tannic acid Schiff base derivatives. The newly compounds were screened for their antibacterial and antifungal potencies.

\section{Chemistry}

Synthesis of tannic acid-glycine derivatives $\left(T G_{1}, T G_{3}, T G_{5}\right)$

Tannic acid $(\mathrm{T})$ was reacted with glycine $(\mathrm{G})$ in different molar ratio $(\mathrm{T}: \mathrm{G}=$ $1: 1,1: 3$ and $1: 5$, respectively) in toluene as a solvent and in presence of $0.1 \%$ by weight of p-toluene sulfonic acid as a dehydrating agent. The reaction was continued under reflux condition until the theoretical amount of water was obtained for each ratio of reactants. The reaction product was filtered and recrystallized twice from acetonitrile, and then obtained tannic acid-glycine derivatives $\left(\mathrm{TG}_{1}, \mathrm{TG}_{3}\right.$ and $\left.\mathrm{TG}_{5}\right)$ were dried under vacuum.

Synthesis of tannic acid-glycine-benzaldehyde derivatives $\left(T G B_{1}, T G B_{3}\right.$, $\left.T G B_{5}\right)$

Tannic acid-glycine derivatives $\left(\mathrm{TG}_{1}, \mathrm{TG}_{3}\right.$ and $\left.\mathrm{TG}_{5}\right)$ were reacted individually by 1,3 and 5 molar ratio of benzaldehyde (B) in ethanol as a solvent under reflux condition for $6 \mathrm{hr}$. The reaction product was filtered off and washed by iso-propanol then dried under vacuum at $40{ }^{\circ} \mathrm{C}$ for $4 \mathrm{hr}$, the obtained tannic acid-glycine Schiff bases were designated as: $\mathrm{TGB}_{1}, \mathrm{TGB}_{3}$ and $\mathrm{TGB}_{5}$ (Scheme 1).

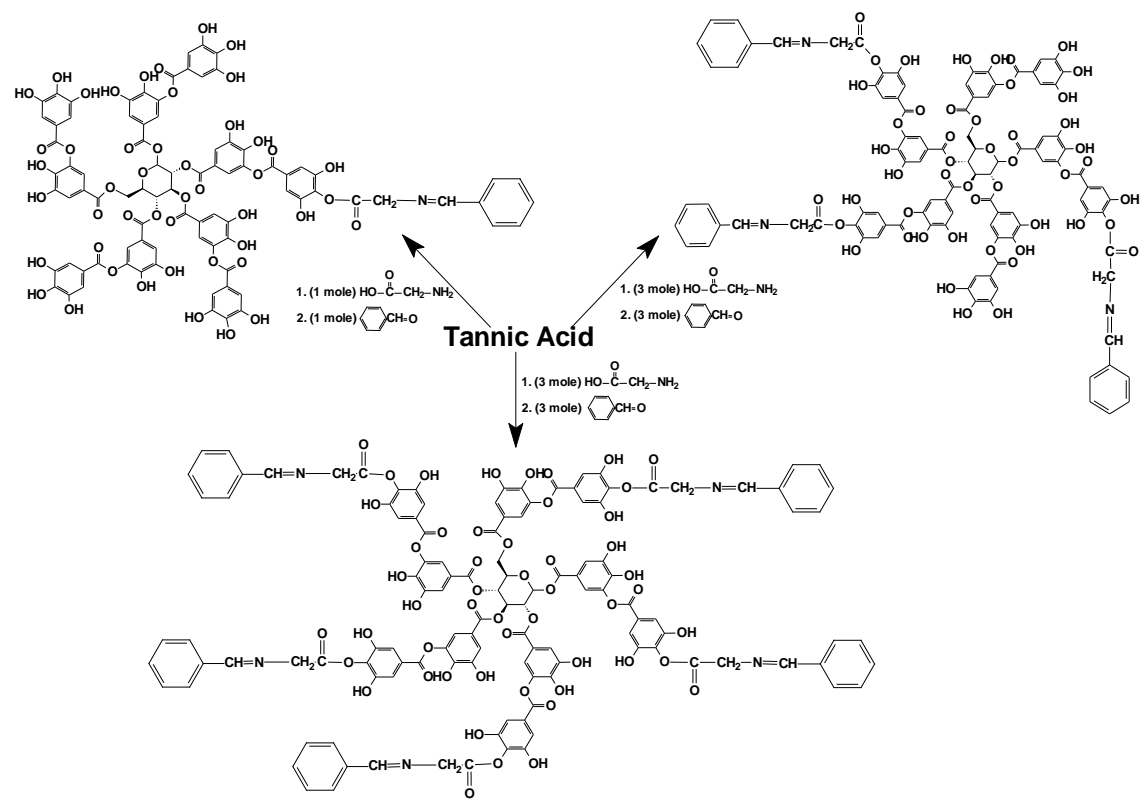

Scheme 1. Synthesis of the surfactants.

Egypt. J. Chem. 55, No. 4 (2012) 


\section{Pharmacology}

Antimicrobial activity measurements

Microorganisms: The tannic acid derivatives were evaluated as biocides against: Staphylococcus aureus ATCC 29213, Escherichia coli ATCC 25922, Pseudomonas aeruginosa ATCC 27853 and Bacillus subtilis ATCC 55422 (ATCC: American Type Culture Collection). And against fungi: Candida albican ATCC 14053 and Aspergillus niger Ferm-BAM-C-21.

Growing of microorganisms: The bacterial strains were cultured according to standards of the National Committee for Clinical Laboratory (NCCLS) ${ }^{(9)}$. The bacterial species grow on nutrient agar consisted of Beef extract $(3.0 \mathrm{~g} / \mathrm{L})$, Peptone $(5.0 \mathrm{~g} / \mathrm{L})$, Sodium chloride $(5.0 \mathrm{~g} / \mathrm{L})$, Agar $(20.0 \mathrm{~g} / \mathrm{L})$ then complete the volume to one liter distilled water. Then the mixture was boiled, and the media was sterilized by autoclave. The bacterial strains were kept on nutrient agar medium and showed no inhibition zones.

\section{Measurements of resistance and susceptibility}

$1.0 \mathrm{ml}$ of inocula was added to $50 \mathrm{ml}$ of agar media $\left(40{ }^{\circ} \mathrm{C}\right)$. The agar was poured into $120 \mathrm{~mm}$ petri dishes and allowed to cool to room temperature. Wells $(6 \mathrm{~mm}$ in diameter) were cut in the agar plates using proper sterile tubes and filled up to the surface of agar with $0.1 \mathrm{ml}$ of $\mathrm{TGB}_{1}, \mathrm{TGB}_{3}$ and $\mathrm{TGB}_{5}$ dissolved in DMF $(2.5 \mathrm{mg} / \mathrm{ml})$. The plates were left on a leveled surface, incubated for $24 \mathrm{hr}$ at $30^{\circ} \mathrm{C}$ and the diameters of the inhibition zones were read. The inhibition zone determined qualitatively the antibacterial activities of these compounds. The mean value of three individual replicates was used to calculate the zone of growth inhibition of each sample. The antimicrobial activity was calculated as a mean of three replicates ${ }^{(10)}$.

\section{Minimum inhibitory concentration (MIC)}

The biocidal activity of the tannic acid Schiff base surfactants $\left(\mathrm{TGB}_{1}, \mathrm{TGB}_{3}\right.$ and $\mathrm{TGB}_{5}$ ) against the tested strains was expressed as the minimum inhibitory concentration (MIC) values, defined as the lowest concentration of compounds inhibiting the development of visible growth after $24 \mathrm{hr}$ of incubation. MIC values were determined by dilution method ${ }^{(10)}$. Biocides were dissolved in distilled water/alcohol $(3 / 1 ; \mathrm{v} / \mathrm{v})$ mixture at various concentrations and $1 \mathrm{ml}$ aliquot of the biocides solutions was added to the $14 \mathrm{ml}$ agar media. The final concentrations of the tested compounds in the medium were $1.25,0.65,0.325$, $0.156,0.1$ and $0.098 \mathrm{mg} / \mathrm{ml}$.

\section{Biodegradability}

Biodegradability test in river water of $\mathrm{TGB}_{1}, \mathrm{TGB}_{3}$ and $\mathrm{TGB}_{5}$ was determined using surface tension method (Du-Noüy tensiometer, Krüss type K6) using platinum ring ${ }^{(11)}$. Each surfactant was dissolved in river water by a concentration of $100 \mathrm{ppm}$ and incubated at $38{ }^{\circ} \mathrm{C}$. A sample was withdrawn daily (for 30 day), filtered and the surface tension value was measured. The biodegradation percent (D \%) was calculated as follows: 


$$
\mathrm{D} \%=\left(\gamma_{\mathrm{t}}-\gamma_{0}\right) /\left(\gamma_{\mathrm{bt}}-\gamma_{0}\right) \times 100
$$

where: $\gamma_{\mathrm{t}}$ is the surface tension at time $\mathrm{t}, \gamma_{\mathrm{o}}$ is the surface tension at time 0 (initial surface tension) and $\gamma_{\mathrm{bt}}$ is the surface tension of river water without addition of surfactants at time $t$.

\section{Measurements}

Surface tension measurements

Surface tension data $(\gamma)$ of the tannic acid Schiff base surfactants $\left(\mathrm{TGB}_{1}\right.$, $\mathrm{TGB}_{3}$ and $\mathrm{TGB}_{5}$ ) (in concentration range of 0.1 to $0.0001 \mathrm{M} / \mathrm{L}$ ) were measured by Du-Noüy tensiometer (Krüss type K6) (Hamburg, Germany) using platinum ring detachment method and was calibrated by deionized water at $25{ }^{\circ} \mathrm{C}$. The surface tension measurements were taken after 1 min of pouring the surfactant solution in the measuring container to ensure the Equilibrium ${ }^{(12)}$.

\section{Viscometric measurements}

The intrinsic viscosities of the prepared compounds were measured in double distilled water at $25{ }^{\circ} \mathrm{C}$ using a capillary viscometer (Übbelhode suspended level type) at surfactant concentrations in the range 0.005-5.0 gL $\mathrm{gL}^{-1}$. The molecular weights were calculated using Equation (2) ${ }^{(13)}$ :

$$
\eta=3.38 \times 10^{-3} \mathrm{M}^{0.43}
$$

The obtained average molecular weights $\left(\mathrm{MWt}^{\mathrm{V}}\right)$ of the different compounds were compared by the expected molecular weights and listed in Table 1.

\section{Gel permeation chromatography (GPC)}

GPC experiments were carried out using a Supremamax 3000 column (Polymer Standard Service, Mainz, Germany) with water (HPLC grade) as eluent $(1 \mathrm{ml} / \mathrm{min})$. The obtained average molecular weights $\left(\mathrm{MWt}^{\mathrm{GPC}}\right)$ of the compounds relative to the standard compounds were listed in Table 1.

\section{Critical micelle concentration (CMC)}

$C M C$ is the concentration of surfactant solution at which the micelles are started to form and determined from the extrapolation of the pre- and post micellar regions of the surface tension versus $-\log C$ profile ${ }^{(14)}$.

\section{Effectiveness $\left(\pi_{c m c}\right)$}

$\pi_{\mathrm{cmc}}$ is the difference between the surface tension of the bidistilled water and the surfactant solution at $C M C$ according to Equation (3):

$$
\pi_{\mathrm{cmc}}=\gamma_{\mathrm{o}}-\gamma_{\mathrm{cmc}}
$$

where $\gamma_{\mathrm{o}}$ is the surface tension of the bidistilled water $(71.8 \mathrm{mN} / \mathrm{m})$ and $\gamma_{\mathrm{cmc}}$ is the surface tension of the surfactant solution at $C M C^{(15)}$. 
Maximum surface excess $\left(\Gamma_{\max }\right)$

$\Gamma_{\max }$ is defined as the maximum concentration of surfactant molecules which can be attained at the air-solution interface and can be calculated according to Equation (4) ${ }^{(16)}$ :

$$
\Gamma_{\max }=(\partial \gamma / \partial \ln C) / R T
$$

where $R$ is the gas constant (8.314) and $T$ is the absolute temperature $\left({ }^{\circ} \mathrm{K}\right)$.

Minimum surface area $\left(A_{\min }\right)$

$A_{\min }$ is the area occupied by each surfactant molecule at the air/solution interface at the maximum saturation condition and can be calculated using Equation (5) ${ }^{(16)}$ :

$$
A_{\min }=10^{16} /\left(N_{\mathrm{av}} \Gamma_{\max }\right)
$$

where $N_{\text {av }}$ is the Avogadro's number and $A_{\min }$ is given in $\mathrm{nm}^{2}$ molecule ${ }^{-1}$.

\section{Results and Discussion}

Structure of tannic acid Schiff base surfactants

The three tannic acid Schiff base surfactants were prepared by the reaction between tannic acid and glycine with different molar ratios $(1: 1,1: 3$ and 1:5) in toluene, and then the esters were condensed by benzaldehyde in absolute ethanol in good yield and purity. The prepared compounds were characterized by microelemental analysis, FTIR and $\mathrm{H}^{1}$-NMR spectroscopy.

\section{Microelemental analysis}

The microelemental data (Elementar Analysensysteme Gmbh) of $\mathrm{TGB}_{1}$, $\mathrm{TGB}_{3}$ and $\mathrm{TGB}_{5}$ showed their purity as the calculated and the found values of the different elements.

IR spectra

The IR spectra (Perkin-Elmer FTIR-2000 spectrometer) showed bands at: $3515,3010,2850,1737,1634,1563$, and $1210 \mathrm{~cm}^{-1}$ corresponded to $\mathrm{O}-\mathrm{H}, \mathrm{C}-\mathrm{H}$ aromatic, $\mathrm{CH}_{2}, \mathrm{C}=\mathrm{O}, \mathrm{C}=\mathrm{N}, \mathrm{C}=\mathrm{C}$ and $\mathrm{C}-\mathrm{O}$ groups.

${ }^{1} H-N M R$ spectroscopy

The ${ }^{1} \mathrm{H}-\mathrm{NMR}$ spectra of $\mathrm{TGB}_{1}$ surfactant was taken as a representative sample (Avance Bruker $300 \mathrm{MHz}$ ) showed signals at: $\delta=1.28 \mathrm{ppm}(\mathrm{m}, 2 \mathrm{H}$, $\left.\mathrm{CH}_{2}\right), 2.64 \mathrm{ppm}\left(\mathrm{t}, 2 \mathrm{H}, \mathrm{OCOCH}_{2}\right), 5.34 \mathrm{ppm}(\mathrm{s}, 1 \mathrm{H}, \mathrm{OH})$.

\section{Molecular weight measurement}

The molecular weights of the surfactants were measured using viscosity and GPC measurements. The obtained molecular weights were comparable to the calculated values within $98 \%$ (Table 1). 
TABLE 1. Theoretical and measured molecular weights, molar conductance, magnetic moment values and elemental analyses data of the synthesized surfactants .

\begin{tabular}{|c|c|c|c|c|c|c|c|c|c|c|}
\hline \multirow{3}{*}{ Surfactant } & \multicolumn{3}{|c|}{$\begin{array}{c}\text { Molecular weight, } \\
\text { g/mole }\end{array}$} & \multirow{3}{*}{$\begin{array}{c}\text { Molar } \\
\text { conductance } \\
\left(\begin{array}{c}\left(\mathrm{hhm}^{-1} \mathrm{~cm}^{-}\right. \\
\left.{ }^{1} \mathrm{~mol}\right)\end{array}\right.\end{array}$} & \multicolumn{6}{|c|}{ Elemental analyses } \\
\hline & & & & & \multicolumn{2}{|c|}{$\mathrm{C} \%$} & \multicolumn{2}{|c|}{$\mathbf{H \%}$} & \multicolumn{2}{|c|}{ N\% } \\
\hline & & & & & Calc & Found & Calc & Found & Calc & Found \\
\hline TGB $_{1}$ & 1846 & 1790 & 1809 & 1.17 & 0.553 & 0.549 & 0.032 & 0.032 & 0.008 & 0.007 \\
\hline TGB $_{3}$ & 2163 & 2150 & 2125 & 1.12 & 0.579 & 0.575 & 0.034 & 0.034 & 0.019 & 0.017 \\
\hline TGB $_{5}$ & 2427 & 2410 & 2400 & 1.03 & 0.599 & 0.595 & 0.036 & 0.036 & 0.029 & 0.027 \\
\hline
\end{tabular}

a . Expected molecular weight, ${ }^{b}$. Calculated from gas chromatography, ${ }^{c}$. Calculated from viscosity measurements.

Surface activity of the tannic acid Schiff base surfactants

The solution of tannic acid in water (maximum solubility of $2850 \mathrm{~g} / \mathrm{L}$ ) has very low surface activity due to the large number of the hydroxyl groups incorporated in the molecule. The introduction of alkyl chains in the molecule is expected to increase its surface activity and decrease its surface tension in the solution. The lowering in surface tension comes from the increase of adsorption tendency of these molecules at the interfaces due to the hydrophobic nature of the chains. Consequently, increasing the number of attached chains to the tannic acid molecules is the reason of the gradual decrease in the surface tension.

Figure 1 represents the dependence of the surface tension of the three tannic acid Schiff base derivatives on their concentrations in the solutions at $25{ }^{\circ} \mathrm{C}$. At constant substitution ratio, i.e., $\mathrm{TGB}_{1}, \mathrm{TGB}_{3}$ or $\mathrm{TGB}_{5}$, there is a gradual decrease in the surface tension values by increasing the concentration of tannic acid solutions. That decrease is attributed to the gradual adsorption of the surfactant molecules by increasing the concentration. Also, at constant concentration the surface tension values are gradually decreased by increasing the ratio of substitution from one to five side chains. The lowest surface tension values were obtained in case of $\mathrm{TGB}_{5}$ surfactants at $25{ }^{\circ} \mathrm{C}$. That can be attributed to the high adsorption tendency of $\mathrm{TGB}_{5}$ at the interface than $\mathrm{TGB}_{1}$ and $\mathrm{TGB}_{3}$ surfactants. The variation of surface tension vs. concentration of the surfactants solutions is characterized by two regions. One at lower concentration with a slope represents the adsorption of the molecules at the interfaces. The second is at higher concentrations with almost constant slope. Extrapolation of the two regions determines the critical micelle concentration values (CMC) of the different surfactants (Table 2). The CMC values of the surfactants (0.00018$0.00065 \mathrm{M} / \mathrm{L}$ ) were relatively small compared to the conventional nonionic surfactants (Tween-80; 0.0009 M/L) ${ }^{(17,18)}$.

Egypt. J. Chem. 55, No. 4 (2012) 


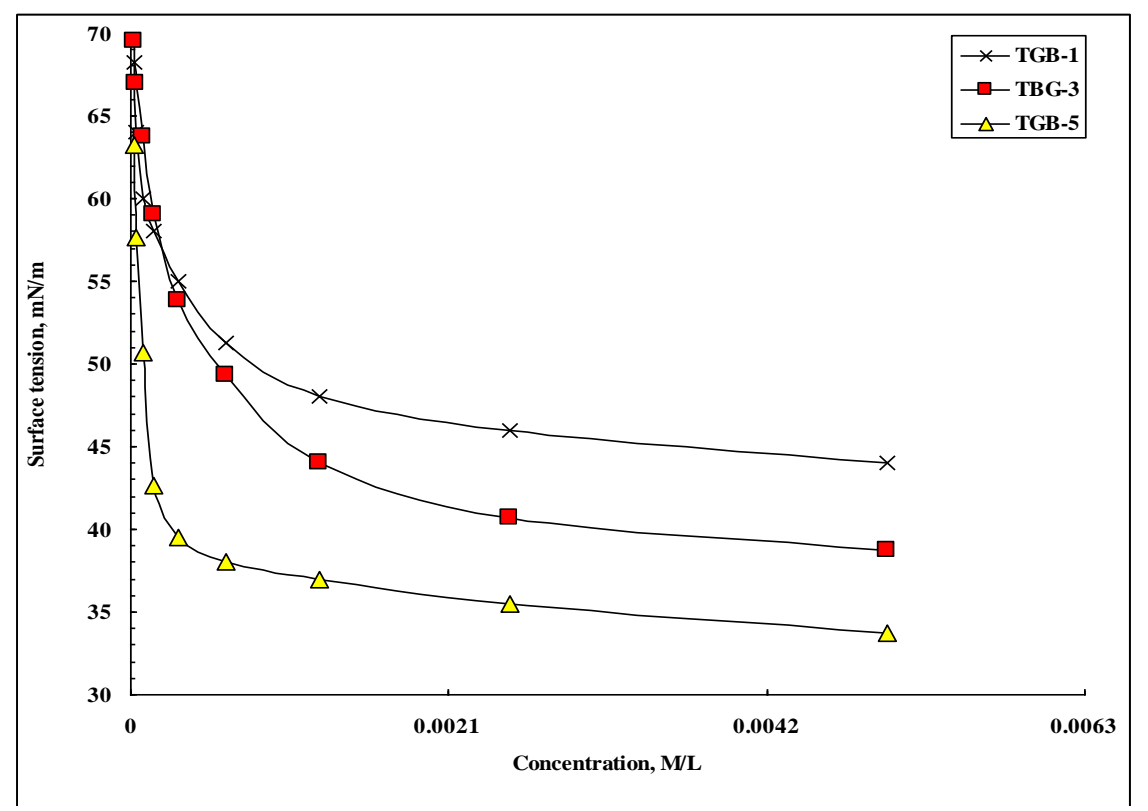

Fig.1. Surface tension vs. concentration of the synthesized tannic acid Schiff base surfactants at $25^{\circ} \mathrm{C}$.

TABLE 2. Critical micelle concentrations, effectiveness, efficiency, maximum surface excess, minimum surface area, emulsification power and biodegradation values of the synthesized surfactants at $25{ }^{\circ} \mathrm{C}$.

\begin{tabular}{|c|c|c|c|c|c|c|c|}
\hline $\begin{array}{c}\text { Surfact } \\
\text { ant }\end{array}$ & $\begin{array}{c}\text { CMCX } \\
10^{-5}, \\
\text { M/L }\end{array}$ & $\begin{array}{c}\text { Effectiv } \\
\text { eness } \\
\left(\pi_{c m c}\right), \\
\text { mN/m } \\
\end{array}$ & $\begin{array}{c}\text { Efficiency } \\
\left(P c_{20}\right) \\
\times 10^{-4} \\
\mathrm{M} / \mathrm{L}\end{array}$ & $\begin{array}{c}\text { Maximum } \\
\text { surface excess } \\
\left(\Gamma_{\max }\right) \times \mathbf{1 0}^{-10}, \\
\text { Mole } / \mathrm{cm}^{2}\end{array}$ & $\begin{array}{c}\text { Minimum } \\
\text { surface area } \\
\left(A_{\text {min }}\right), \\
\mathrm{nm}^{2} / \mathbf{m o l e c u l e} \\
\end{array}$ & $\begin{array}{c}\text { Emulsific } \\
\text { ation, } \\
\text { Sec. }\end{array}$ & $\begin{array}{c}\text { Biodegrad } \\
\text { ation, } \\
\%\end{array}$ \\
\hline TGB $_{1}$ & 64.5 & 23.3 & 5.8 & 1.95 & 84.96 & 240 & $100^{*}$ \\
\hline TGB $_{3}$ & 40.5 & 28.3 & 5.5 & 2.83 & 58.73 & 540 & $94^{*}$ \\
\hline TGB $_{5}$ & 18.1 & 33.8 & 0.7 & 3.67 & 45.26 & 1200 & $80^{*}$ \\
\hline
\end{tabular}

The efficiency $\left(P c_{20}\right)$ is the concentration of the surfactant which suppresses the surface tension of the solution by 20 surface tension unit $(\mathrm{mN} / \mathrm{m})$. Comparing the values of $P c_{20}$ in Table 2 revealed that, $P c_{20}$ decreases by complexation and the increase of substitution on the surfactant molecule.

The highest $\Gamma_{\max }$ value was obtained for $\mathrm{TGB}_{5}$ surfactant, which indicates its strong adsorption at the air-water interface than $\mathrm{TGB}_{1}$ and $\mathrm{TGB}_{3}$. That was in good agreement with the variation of the surface tension values showed in Fig. 1. 
Water molecules adjacent to hydrophobic parts of surfactant molecules are forming a shell-like structure via hydrogen bonding. This is called 'iceberg structure' because of its similarity to the structure of ice ${ }^{(19)}$. This effect increases the tendency of the molecules to form micelles in the bulk of their solutions at comparatively low concentrations. $A_{\min }$ values decreased by increasing the number of substitutions on the tannic acid molecule in the sequence of: $\mathrm{TGB}_{1}>\mathrm{TGB}_{3}>\mathrm{TGB}_{5} . A_{\min }$ of $\mathrm{TGB}_{1}$ molecule at the interface is $84.96 \mathrm{~nm}^{2}$, which indicates that the molecules are planner ${ }^{(19)}$. The gradual increase of the substituents on the tannic acid molecule decreases $A_{\min }$ to reache the minimum in case of $\mathrm{TGB}_{5}$. That is due to the overlapping between the side chains, which twists the surfactant molecules and decreases the actual area at the interface (Table 2).

\section{Antimicrobial assay}

Antibacterial activities (zone of growth inhibition and minimal inhibitory concentrations) of the synthesized surfactants and Amikacin ${ }^{\mathrm{TM}}$ (as a standard compound) are shown in Tables $3 \& 4$. Obtained data indicate high antimicrobial activity of the three tannic acid Schiff base surfactants against Gram-negative bacteria, $P$. aeruginosa and E. coli, and moderate potency against Grampositive bacteria, B. subtilus and S. auerus (compared to Amikacin). On the other hand, the three surfactants showed high potency against $C$. albican and $A$. niger. The antimicrobial activity decreased by increasing the number of substituents in the following order: $\mathrm{TGB}_{1}>\mathrm{TGB}_{3}>\mathrm{TGB}_{5}$. It is reported that the action mode of the biocides is the adsorption onto the cell membranes, which decreases their osmotic stability and leads to the leakage of intracellular constituents ${ }^{(20)}$. The adsorption onto the cellular membranes mainly occurred due to the presence of polar groups of the biocide molecules. The antimicrobial efficacy of the biocides arises from the presence of azomethine groups $(-\mathrm{CH}=\mathrm{N}-)$ which impart in explanation of the mechanism of transformation reaction in biological system and also from the presence of the several hydroxyl groups, which may play an effective role in the antibacterial activity of these compounds ${ }^{(21)}$. However, the exact mechanism of the antimicrobial action is still unknown and several mechanisms may contribute to the antimicrobial action. These mechanisms include the formation of an impermeable coat on the bacterial surface ${ }^{(20)}$, uptake of low molecular weight biocides that will interact with electronegative substances in the cell ${ }^{(20)}$, and inhibition of bacterial growth through chelation of trace metals ${ }^{(21)}$. The interaction mechanism differs for Gram-positive to Gram-negative bacteria. Gram-negative bacteria are more resistant to antimicrobial agents than Gram-positive bacteria are due to the differences in the cellular membrane structures of the two bacterial types ${ }^{(22)}$. The membrane of the Gram-negative bacteria is entirely composed of cross linked lipopolysaccharides and proteins which resist the entrance and effects of biocide molecules ${ }^{(23)}$. Hence, the perturbation of this membrane requires a fine tuning of the hydrophobic-hydrophilic balance. In our results, the tested biocides were more efficient against Gram-negative bacteria than Gram-

Egypt. J. Chem. 55, No. 4 (2012) 
positive bacteria. That comprises the applicability of these compounds, where the conventional biocides failed, in defeating the Gram-negative bacterial strains growth. The quantitative assays gave MIC values in the range 0.097$1.25 \mathrm{mg} / \mathrm{ml}$ (Table 4), which confirmed the above obtained results.

TABLE 3. Quantitative antimicrobial assay results (zone of growth inhibition) of the free tannic acid Schiff base surfactants and related metal complexes .

\begin{tabular}{|c|c|c|c|c|c|c|}
\hline \multirow[b]{3}{*}{ Surfactant } & \multicolumn{6}{|c|}{ Microorganisms } \\
\hline & \multicolumn{2}{|c|}{ Gram-positive bacteria } & \multicolumn{2}{|c|}{ Gram-negative bacteria } & \multicolumn{2}{|c|}{ Fungi } \\
\hline & $\begin{array}{c}\text { Bacillus } \\
\text { subtillus, } \\
\text { NCIB- } \\
3610\end{array}$ & $\begin{array}{c}\text { Staphylococcus } \\
\text { auerus, } \\
\text { NCTC-7447 }\end{array}$ & $\begin{array}{c}\text { Pseudomonas } \\
\text { aeruginosa, } \\
\text { NCIB-9016 }\end{array}$ & $\begin{array}{c}\text { Escherichia } \\
\text { coli, } \\
\text { NCTC- } \\
10416\end{array}$ & $\begin{array}{c}\text { Candida } \\
\text { albican, } \\
\text { ATCC } \\
14053\end{array}$ & $\begin{array}{l}\text { Aspergillus } \\
\text { niger, } \\
\text { Ferm- } \\
\text { BAM C-21 }\end{array}$ \\
\hline TGB $_{1}$ & 17 & 18 & 19 & 19 & 20 & 24 \\
\hline TGB $_{3}$ & 15 & 17 & 17 & 19 & 19 & 22 \\
\hline TGB $_{5}$ & 15 & 16 & 16 & 16 & 15 & 20 \\
\hline
\end{tabular}

TABLE 4. Quantitative antimicrobial assay results (minimal inhibitory concentrations, MIC) of the free tannic acid Schiff base surfactants and related metal complexes .

\begin{tabular}{lcccccc}
\hline & \multicolumn{7}{c}{ Microorganisms } \\
\cline { 2 - 8 } Surfactant & Gram-positive bacteria & Gram-negative bacteria & \multicolumn{2}{c}{ Fungi } \\
\cline { 2 - 8 } & $\begin{array}{c}\text { Bacillus } \\
\text { subtillus, } \\
\text { NCIB- } \\
\text { 3610 }\end{array}$ & $\begin{array}{c}\text { Staphylococcus } \\
\text { auerus, } \\
\text { NCTC-7447 }\end{array}$ & $\begin{array}{c}\text { Pseudomonas } \\
\text { aeruginosa, } \\
\text { NCIB-9016 }\end{array}$ & $\begin{array}{c}\text { Escherichia } \\
\text { coli, } \\
\text { NCTC- } \\
\mathbf{1 0 4 1 6}\end{array}$ & $\begin{array}{c}\text { Candida } \\
\text { albican, } \\
\text { ATCC } \\
\mathbf{1 4 0 5 3}\end{array}$ & $\begin{array}{c}\text { Aspergillus } \\
\text { niger, } \\
\text { Ferm- } \\
\text { BAM C-21 }\end{array}$ \\
\hline TGB $_{\mathbf{1}}$ & 1.25 & 0.312 & 0.312 & 0.312 & 0.312 & 0.312 \\
\hline TGB $_{\mathbf{3}}$ & 0.625 & 0.625 & 0.625 & 0.625 & 0.625 & 0.625 \\
\hline $\mathbf{T G B}_{\mathbf{5}}$ & 1.25 & 1.25 & 1.25 & 1.25 & 1.25 & 0.625 \\
\hline
\end{tabular}

Biodegradability

Biodegradation is the conversion of organic compounds into less complex structures under the influence of microorganisms. In the aerobic conditions, this process results in formation of water, carbon dioxide, and biomass. The biodegradation rate of surfactant molecules depends on their chemical structures, concentration, $\mathrm{pH}$ and temperature ${ }^{(24)}$. In traditional surfactants, the rate of biodegradation varied from 1-2 hr for fatty acids derived surfactants; $1-2$ days for linear alkyl benzene sulphonates, and several months for branched alkyl benzene sulphonates (ABS). Two criteria are important when testing for biodegradation: first, primary degradation that results in loss of surface activity. Second, ultimate biodegradation, i.e. conversion into $\mathrm{CO}_{2}$, which can be measured using closed bottle tests. The biodegradability of $\mathrm{TGB}_{1}, \mathrm{TGB}_{3}$, and 
$\mathrm{TGB}_{5}$ was evaluated and followed using (Die-away test) described by Naylor et al. ${ }^{(25)}$. The results of biodegradation using Die-away test in the river water reflected the fact that, lowering of the surface tension is a reverse function of biodegradation. It is clear from the data in Table 2 that the biodegradation ratios of the biocides are ranged between 80 and $100 \%$ after 28 day. In addition, there is a direct relationship between the number of substituents and the percent of biodegradation. Compound $\mathrm{TGB}_{1}, \mathrm{TGB}_{3}$ and $\mathrm{TGB}_{5}$ showed gradual increase in the degradation $\%$ after 28 days. These values specified these biocides as biodegradable compounds and pass the international level (70\% after 28 days). That permits the surfactants as readily biodegradable compounds. These good results contrast with the low biodegradation level of the classical nonionic surfactants ${ }^{(26)}$. In fact, the biocides have been designed from a naturally occurring compound (tannic acid and glycine) which has the ability to degrade by the action of the environmental microorganisms. The degradation of tannic acid was confirmed by the evidence of its degradation products, gallic acid and glucose, as reported by Van Diepeningen et al., ${ }^{(27)}$. The reported pathway of biodegradation considered in case of the compounds is that the microorganisms firstly attach the tannic acid moiety and then the substituents degraded through $\beta$-oxidation pathway which includes the chain-shortening and finally the microorganisms completely degrade the hydrocarbon chain to carbon dioxide and water.

\section{Conclusions}

In this work three tannic acid Schiff base derivatives were synthesized. The compounds showed good cytotoxicity against several bacterial and fungal strains. The derivatives containing one Schiff base moiety showed higher antimicrobial activity than those containing three or five moieties. The inhibition mechanism towards Gram-positive or Gram-negative bacteria was explained according to adsorption theory. The compounds showed noticeable biodegradability in the environment as a comprise feature of their parent compound, tannic acid.

\section{References}

1. Wegrzynska J., Chlebicki J. and Maliszewska, I., Preparation, surface-active properties and antimicrobial activities of bis(ester quaternary ammonium) salts. $J$ Surf. Deterg. 10,109-116 (2007) .

2. Rego, J.V., Amoros, R.L., Garcia, M.T., Comas, J. and Leal, J.S., Microbial aspects of linear alkylbenzene sulfonate degradation in coastal water. J. Surf. Deterg . 3, 303$308(2000)$.

3. Amine, M.S., Mahmoud, A.A., Badr, S.K. and Gouda, A.S., Fatty acids in heterocyclic synthesis part xii: synthesis of surfactants from pyrazole, isoxazole, pyrimidine and triazine, incorporating the 1,3,4-thiadiazole moiety having dyeing and antimicrobial activities. J. Surf. Deterg. 15, 79-190 (2012) . 
4. Negm, N.A., Aiad, I.A. and Tawfik, S.M., Screening for potential antimicrobial activities of some cationic Uracil biocides against wide-spreading bacterial strains. $J$. Surf. Deterg. 13, 03-511 (2010) .

5. Serdons, K., Verduyckt, T., Vanderghinste, D., Borghgraef, P., Cleynhens, J., Leuven, F.V., Kung, H., Bormans, G. and Verbruggen, A., ${ }^{11} \mathrm{C}$-labelled PIB analogues as potential tracer agents for in vivo imaging of amyloid beta in Alzheimer's disease. Eur. J. Med. Chem. 44, 1415-1426 (2009) .

6. Wang, L., Yang, F., Yang, X., Guan, X., Hu, C., Liu, T., He, Q., Yang, B. and Hu, Y., Synthesis and biological evaluation of new 4 $\beta$-anilino-4'-O-demethyl-4desoxypodophyllotoxin derivatives as potential antitumor agents. Eur. J. Med. Chem. 42, 285-296 (2011) .

7. Bayrak, H., Demirbas, A., Karaoglu, S.A. and Demirbas, N., Synthesis of some new 1,2,4-triazoles, their Mannich and Schiff bases and evaluation of their antimicrobial activities. Eur. J. Med. Chem. 44,1057-1066 (2009) .

8. Banno, T., Toshima, K., Kawada. K. and Matsumura, S., Synthesis and properties of gemini-type cationic surfactants containing carbonate linkages in the linker moiety directed toward green and sustainable chemistry. J. Surf. Deterg. 12, 249-259 (2009) .

9. Negm, N.A., Aiad, I.A. and Tawfik, S.M., Screening for potential antimicrobial activities of some cationic Uracil biocides against wide spreading bacterial strains. $J$. Surf. Deterg . 13, 503-511 (2010) .

10. National Committee for Clinical Laboratory Standards, Methods for dilution antimicrobial susceptibility tests for bacteria that grow aerobically. National Committee for Clinical Laboratory Standards, Wayne. (1997) .

11. EL-Sukkary, M.M.A., Sayed, N.A., Aiad, I.A., Helmy, S.M. and EL-Azab, W.I.M., Aqueous solution properties, biodegradability, and antimicrobial activity of some alkyl polyglycosides surfactants. Tenside. Surf. Det. 46, 311-316 (2009) .

12. Negm, N.A., Salem, M.A.I., Badawi, A.M., and Zaki, M.F., $7^{\text {th }}$ International Conference of Chemical Engineering, Cairo, Egypt, 27-29 December (2004) .

13. Yan, R.X., Water-soluble Polymers, Chemical Industry Press, Beijing (1998) .

14. Negm, N.A. and Mohamed, A.S., Surface and thermodynamic properties of diquaternary bola-form amphiphiles containing aromatic spacer. J. Surf. Deterg. 7, 23-30 (2004) .

15. Negm, N.A., Solubilization, surface active and thermodynamic parameters of gemini amphiphiles bearing nonionic hydrophilic spacer. J. Sur.f Deterg. 10, 71-80 (2007) .

16. Negm, N.A. and Aiad, I.A., Synthesis and characterization of multifunctional surfactants in oil-field protection applications. J. Surf. Deterg. 10, 87-92 (2007) . 
17. Negm, N.A., Ghuiba, F.M., Mahmoud, S.A. and Tawfik, S.M., Biocidal and anticorrosive activities of benzoimidazol-3-ium cationic Schiff base surfactants. Eng. Life Sci. 11, 496-510 (2011).

18. Rosen, M.J., Surfactants and Interfacial Phenomena, $2^{\text {nd }}$ Ed, John Wiley \& Sons, New York (1989) .

19. Tanford, C., The Hydrophobic Effect: Formation of Micelles and Biological Membranes. $2^{\text {nd }}$ Ed., Wiley, New York (1980).

20. Perez, L., Pinazo, A., García, M.T., Lozano, M., Manresa, A., Angelet, M., Vinardell, M.P., Mitjans, M., Pons, R. and Infante, M.R., Cationic surfactants from lysine: Synthesis, micellization and biological evaluation. Eur. J. Med. Chem, 44, 1884-1892 (2009) .

21. Negm, N.A., El Farargy, A.F., Mohammed, D.E. and Mohamad, H.N., Environmentally friend nonionic surfactants derived from tannic acid: Synthesis, characterization and influence of structure on the surface activity. J. Surf. Deterg. DOI: $10.1007 / \mathrm{s} 11743-011-1326-8$ (2012) .

22. Hafiz, A.A., Badawi, A.M., El-Deeb, F.I., Soliman, E.A. and El-Awady, M.Y., Ferrocene-based cationic surfactants: Surface and antimicrobial properties. J. Surf. Deterg. 13, 165-172 (2010) .

23. Kuperkar, K., Modi, J. and Patel, K., Surface-active properties and antimicrobial study of conventional cationic and synthesized symmetrical Gemini surfactants . J. Surf. Deterg. 15, 107-115 (2012) .

24. Aiad, I.A., Badawi, A.M., El-Sukkary, M.M., El-Sawy, A.A. and Adawy, A.I., Synthesis and biocidal activity of some naphthalene-based cationic surfactants. J. Surf Deterg. 15, 223-234 (2012) .

25. Naylor, C.G., Williams, J.B., Varineau, P.T., Yunick, R.P., Serak, K., Cady, C. and Severn, D.J., $19^{\text {th }}$ Annual Society Environmental Toxicology and Chemistry, (1998) .

26. Negm, N.A., El Farargy, A.F.M., Mohammed, D.E. and Mohamad, H.N., Environmentally friendly nonionic surfactants derived from tannic acid: Synthesis, characterization and surface activity. J. Surf. Deterg. 15, 433-443 (2012) .

27. Van Diepeningen, A.D., Debets, A.J., Varga, J., van der Gaag, M., Swart, K., Hoekstra, R.F., Efficient degradation of tannic acid by black. Aspergillus species. Mycol. Res. 108, 919-25 (2004). 


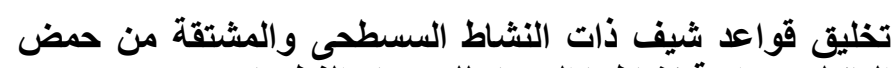
التانيك ودراسة نشاطها المضاد للبكتريا والفطريات

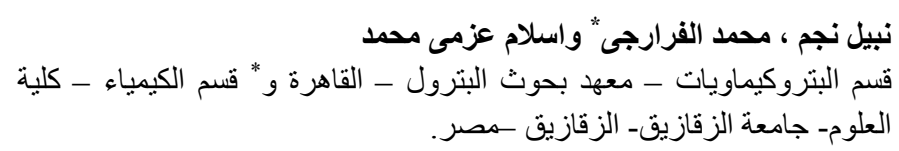

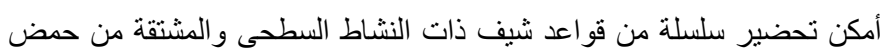

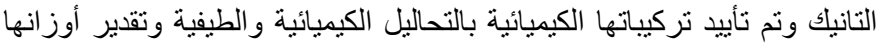

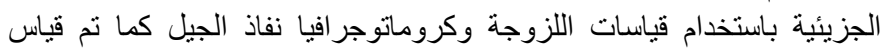

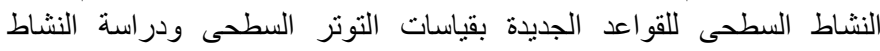

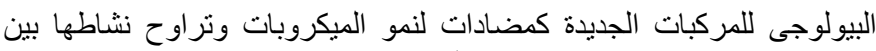

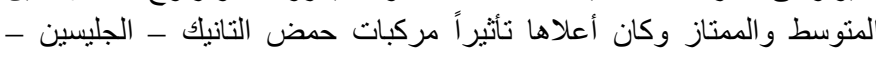

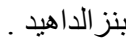

